Ann. Génét. Sél. anim., I975, 7 (2), 205-223.

\title{
CHANGES OF SCALE IN THE STUDY OF THE EVOLUTION OF THE GENETIC VARIANCE THROUGH SELECTION IN TRIBOLIUM CASTANEUM
}

\author{
F. OROZCO \\ Departamento de Genética, \\ Inst. Nac. de Investigaciones Agrarias, \\ Avenida de Puerta de Hierro, \\ Madrid-3 (Spain)
}

\section{SUMMARY}

In two different selection experiments for high egg laying of virgin females of Tribolium castaneum, the evolution of the phenotypic, genetic and environmental variances, as selection progresses, has been studied.

In the control (unselected) lines, a strong correlation between the mean and the phenotypic variance was found. Several scale transformations were assayed in order to find a more correct scale. It was found that the best transformation, $i . e$. the one in which the mean and the variance become uncorrelated, is that in which a new variable $Z$ is considered such that : $Z=x / \sqrt{\bar{x}}$.

By applying this transformation to the selected populations, the drastic increase of the phenotypic variance observed in the selected lines was reduced and the evolution, through selection, of the three variances considered can be more clearly seen. A study of that evolution has been made by considering its relationship with the different levels of performance attained in each line and the selection type applied.

The lack of reduction of the genetic variance observed in the selected lines is discussed on the basis of heterozygous superiority, either direct overdominance for the selected trait or overdominance for reproductive traits, in connexion with the observed deterioration of fitness in the selected lines and the increasing importance of the non-additive variation when the trait is measured in stress environments.

The importance of an adequate data transformation for a correct interpretation of results on selection experiments, mainly for parameter estimations and for corrections with control populations, is stressed.

\section{INTRODUCTION}

There are few studies on the evolution of the variance and its components through a process of selection. In purely theoretical terms CROw and KIMURA (I970) showed that in an infinitesimal model the variance does not change under selection and in a non-infinitesimal model the change in the variance gets smaller as the num- 
ber of loci responsible for the expression of the selected trait increases. BULMER (I97I) presents a situation in which there can be a reduction in the genetic variance with selection even in the infinitesimal model, but that variance is restored to its original value when selection is stopped ; that being due to the presence of the so called " joint disequilibrium ". In practical cases, with a finite number of loci acting on the character, a reduction in genetic variance must be expected when selection progresses. This has been, sooner or later, the case in the majority of the long-term selection experiments reported in the literature, but it is also frequent to find that even when the lines arrive to a plateau, generally the additive variance has not been exhausted yet.

To refer here to the literature concerning long-term selection experiments would be cumbersome but, in general, there are few references to the evolution of the variances. Even fewer authors have tried to discuss extensively that evolution if presented; being the work of CLAYTON and RoBERTSON (I957) one of the most complete in this aspect. In general, those experiments are characterised by a first stage of positive response of variable duration with no apparent reduction in genetic variability, followed by a second stage in which the response is still positive but reduced and the additive variability clearly decreases; later on a third stage follows in which the lines arrive to a more or less definite plateau with high fluctuations in the mean and the variances and, sometimes, with surprising changes in them. The first two stages follow from the actual theory of the prediction of selection response but the situation in the third stage is completely impredictible, the factors leading to the attainment of a selection limit being very different for different organisms, traits and situations.

In the difficulty of interpretation of the third stage there may be several causes involved, among them : high proportion of non-additive genetic variance still present if only the additive one was utilized, the phenomenon of natural selection opposing artificial selection, the increase in the level of inbreeding of the selected lines, a larger influence of the environmental effects as the degree of homozygosis increases, etc. Also, the problematic estimation of parameters in cases when regular statistical methods should not be applied. All these facts can illustrate the difficulty of treating this third stage and the surprising and anarchical pattern of the results usually found.

Finally, one point that is frequently commented but very few times seriously taken into account is the problem of choosing an adequate scale to measure the trait and subsequently to estimate the variance components. There is a real difficulty to find the adequate transformation in each case as it is probably not the same for the whole process of selection, and this renders this task more difficult.

Using data from our Tribolium experiments a tentative way to treat the problem of the evolution of the variance in selection experiments is presented here, introducing a type of data transformation in order to obtain more meaningful results.

\section{MATERIAL AND METHODS}

In order to analyze the evolution of the variance through a process of selection, some lines belonging to two experiments out of many available selected lines of Tribolium castaneum were picked out. These two experiments are : a) A genotype-environment interaction study with lines 
selected by different methods to increase or decrease egg laying at three different temperatures. It will be denominated $\mathrm{GE}$ and in the present analysis only within-line type of selection for high egg laying will be included, with a brief reference to some reciprocal recurrent selection data. b) An experiment studying the influence of selection intensity on selection response for high egg production after a large number of generations. This will be called SI. Control lines were run in both experiments as shown in table $\mathrm{I}$. In both cases the selected trait was egg number laid between the 7 th and the I Ith days after adult emergence. The pertinent details for these lines are given in table $x$ and more information on these experiments can be found in Orozco and BELL (1974 a, b) ; Orozco (1974) and RUANo et al. (1975). We will only be concerned here with the first 20 (GE), and 25 (SI) generations of selection.

\section{TABLE I}

Line designation, proportion selected and environment

Numérotation des lignées, intensité de la sélection et environnement

\begin{tabular}{|c|c|c|c|c|c|}
\hline \multicolumn{3}{|c|}{ Experiment GE } & \multicolumn{3}{|c|}{ Experiment SI } \\
\hline $\begin{array}{c}\text { Temp. } \\
\left({ }^{\circ} \mathrm{C}\right)\end{array}$ & \multicolumn{2}{|c|}{$\begin{array}{l}\text { Lines } \\
\text { and } \\
\text { Replicates }\end{array}$} & $\begin{array}{l}\text { Percentage } \\
\text { of } \\
\text { selection }\end{array}$ & \multicolumn{2}{|c|}{$\begin{array}{l}\text { Lines } \\
\text { and } \\
\text { Replicates }\end{array}$} \\
\hline 28 & $\begin{array}{l}\text { AF-I } \\
\text { CF-I* }\end{array}$ & $\begin{array}{l}\text { AF-II } \\
\text { CF-II* }\end{array}$ & $\begin{array}{r}5 \\
10\end{array}$ & $\begin{array}{l}\text { A-I } \\
\text { B-I }\end{array}$ & $\begin{array}{l}\text { A-II } \\
\text { B-II }\end{array}$ \\
\hline 33 & $\begin{array}{l}\text { AN-I } \\
\text { CN-I* }\end{array}$ & $\begin{array}{l}\text { AN-II } \\
\text { CN-II* }\end{array}$ & $\begin{array}{l}20 \\
33\end{array}$ & $\begin{array}{l}\text { C-I } \\
\text { D-I }\end{array}$ & $\begin{array}{l}\text { C-II } \\
\text { D-II }\end{array}$ \\
\hline 38 & $\begin{array}{l}\text { AT-I } \\
\text { CT-I* }\end{array}$ & $\begin{array}{l}\text { AT-II } \\
\text { CT-II* }\end{array}$ & $\begin{array}{r}50 \\
100\end{array}$ & $\begin{array}{l}\text { E-I } \\
\text { F-I* }\end{array}$ & $\begin{array}{l}\text { E-II } \\
\text { F-II* }\end{array}$ \\
\hline \multicolumn{3}{|c|}{20 p. 100 of selection } & \multicolumn{3}{|c|}{ Selection at $33^{\circ} \mathrm{C}$} \\
\hline
\end{tabular}

* Unselected controls.

\section{RESUL'TS}

Figures I and 2 present the selection response in both experiments and figures 3 and 4 give different types of variances plus the coefficient of variation plotted against generation number. Tables 2 and 3 present the linear regression coefficient of several of these parameters on generations. Finally, figures 5 and 6 give the heritability coefficient of both experiments plotted against generation number.

In both experiments the phenotypic variance $\left(\sigma_{\mathrm{p}}^{2}\right)$ increases drastically at least in the first stages, which are those showing the largest response. The genetic (additive) variance $\left(\sigma_{A}^{2}\right)$ also presents a clear ascending trend during the first generations followed by a rather horizontal tendency. However, it is obvious that this increase in both variances must be due to a scale effect : the variance increasing as the mean becomes larger. One clear proof of the existence of that scale effect is the observed trend for the coefficient of variation (CV) : as the $\sigma_{P}^{2}$ increases the $\mathrm{CV}$ decreases in 


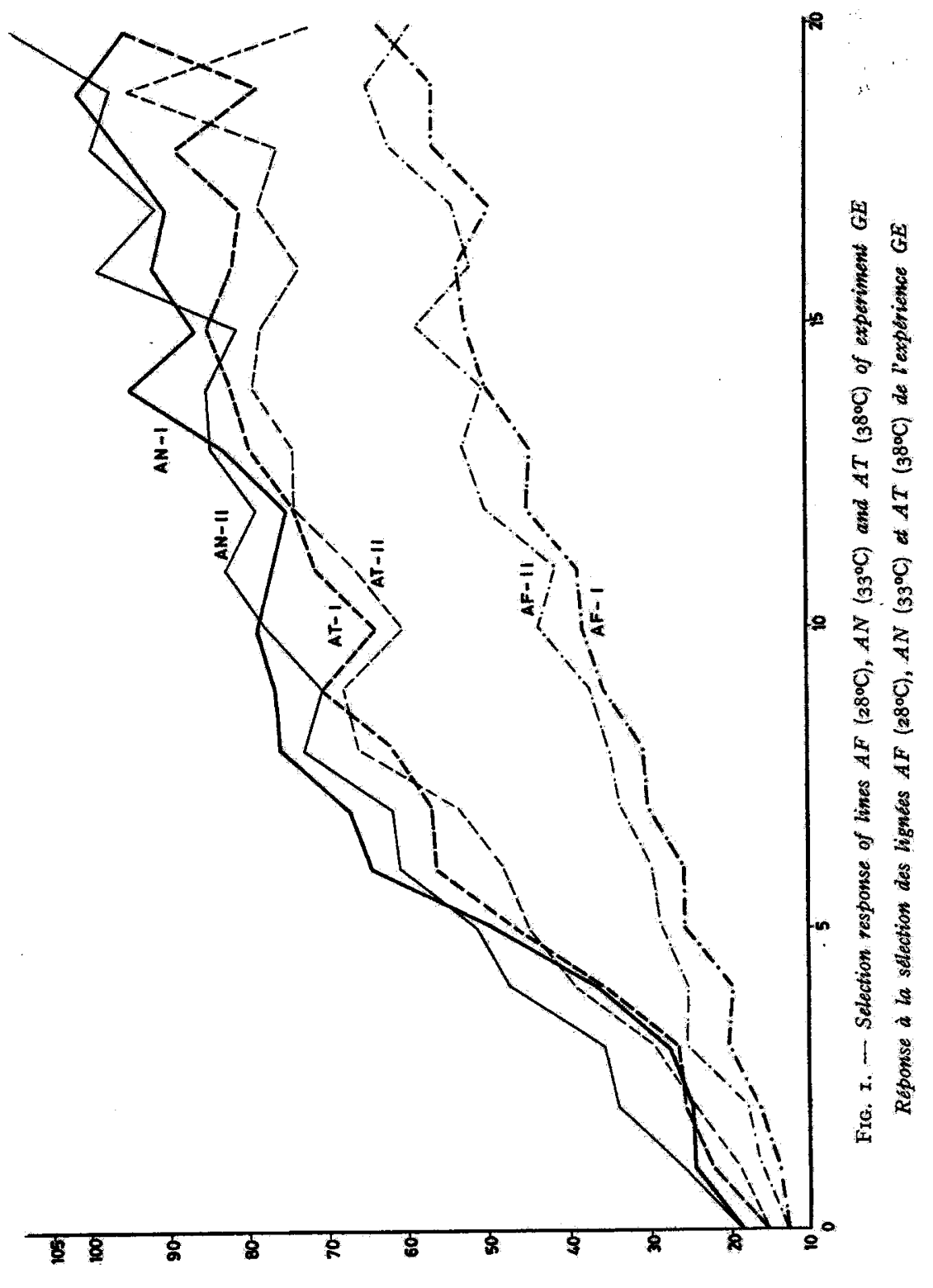

$\exists \perp \forall Y$ งNIA 


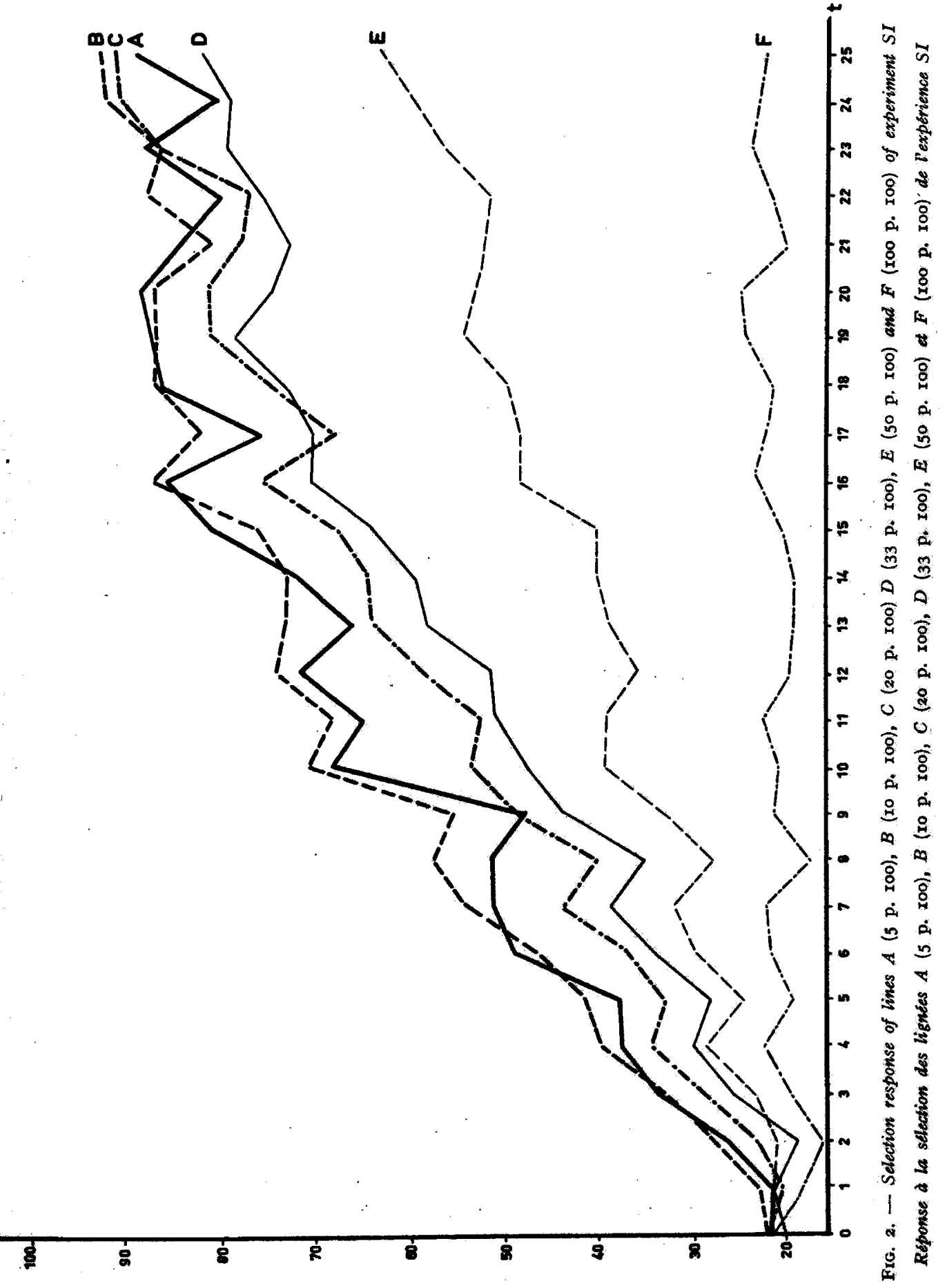


TABLE 2

Linear regression of several parameters on generations.

Replications pooled. Experiment GE

Régression linéaire de plusieurs paramètres mesurée par les générations.

Répétitions groupées. Expérience GE

\begin{tabular}{|c|c|c|c|c|c|}
\hline Line & Generation & $\sigma_{\mathrm{P}}^{2}$ & $\sigma_{A}^{2}$ & $h^{2}$ & $\mathrm{CV}$ \\
\hline $\mathbf{A F}$ & $\begin{array}{l}0-9 \\
0-20\end{array}$ & $\begin{array}{r}20.31 \pm 2.21^{* *} \\
9.95 \pm 1.60^{* *}\end{array}$ & $\begin{array}{l}4.96 \pm 1.58^{*} \\
1.52 \pm 0.77^{\star}\end{array}$ & $\begin{array}{l}-0.003 \pm 0.009 \\
-0.004 \pm 0.003\end{array}$ & $\begin{array}{l}-1.55 \pm 0.33^{* *} \\
-1.62 \pm 0.12^{* *}\end{array}$ \\
\hline AN & $\begin{array}{l}0-9 \\
0-20\end{array}$ & $\begin{array}{l}44.71 \pm 5.88^{* *} \\
14.70 \pm 4.46^{* *}\end{array}$ & $\begin{array}{r}6.07 \pm 7.36 \\
-3.31 \pm 1.98\end{array}$ & $\begin{array}{l}-0.019 \pm 0.013 \\
-0.017 \pm 0.003^{* *}\end{array}$ & $\begin{array}{l}-3.88 \pm 0.32^{* *} \\
-1.92 \pm 0.22^{* *}\end{array}$ \\
\hline AT & $\begin{array}{l}0-9 \\
0-20\end{array}$ & $\begin{array}{r}35.43 \pm 6.50^{* *} \\
9.28 \pm 2.84^{* *}\end{array}$ & $\begin{array}{l}6.93 \pm 1.40^{* *} \\
-0.88 \pm 1.17\end{array}$ & $\begin{array}{l}-0.015 \pm 0.007^{\star} \\
-0.011 \pm 0.003^{* *}\end{array}$ & $\begin{array}{l}-4.79 \pm 0.52^{* *} \\
-2.22 \pm 0.27^{* *}\end{array}$ \\
\hline
\end{tabular}

** $(\mathrm{P}<0.01)$

$*(P<0.05)$

$\star(\mathrm{P}<0.10)$

TABLE 3

Linear regression of several parameters on generations.

Replications pooled. Experiment SI

Régression linéaire de plusieurs paramètres mesurée par les générations.

Répétitions groupées. Expérience SI

\begin{tabular}{c|c|c|c|c}
\hline \hline Lines & \multicolumn{1}{|c|}{$\sigma_{\mathbf{P}}^{2}$} & $\sigma_{\mathrm{A}}^{2}$ & $h^{2}$ & \\
\hline & & & & \\
$\mathrm{A}$ & $20.32 \pm 5.50^{* *}$ & $2.20 \pm 2.32$ & $-0.003 \pm 0.002$ & $-1.22 \pm 0.11^{* *}$ \\
$\mathrm{~B}$ & $18.38 \pm 3.96^{* *}$ & $0.26 \pm 1.72$ & $-0.007 \pm 0.003^{*}$ & $-1.38 \pm 0.14^{* *}$ \\
$\mathrm{C}$ & $21.77 \pm 3.05^{* *}$ & $8.00 \pm 1.08^{* *}$ & $0.002 \pm 0.002$ & $-1.33 \pm 0.11^{* *}$ \\
$\mathrm{D}$ & $18.72 \pm 2.78^{* *}$ & $5.60 \pm 1.46^{* *}$ & $0.001 \pm 0.002$ & $-1.31 \pm 0.10^{* *}$ \\
$\mathrm{E}$ & $13.72 \pm 1.37^{* *}$ & $3.92 \pm 1.54^{*}$ & $-0.001 \pm 0.004$ & $-1.01 \pm 0.12^{* *}$ \\
\hline
\end{tabular}

$* * P<0.01$

$* \mathrm{P}<0.05$

these lines selected for high egg lay, the reverse being true in those lines selected for low egg production in the GE experiment (not included here). The second and definitive proof for the presence of the scale effects is found analyzing the correlation between the mean and the variance. It is worthwhile to indicate that the investigation of the correlation between means and variances to check for a possible scale 
effect in the measure of a selected trait, must be done in samples of the same genetic constitution, because if one expects some changes in the variances through the selection process, a genetic correlation between such parameters will be necessarily found when using data from many generations.

The study to investigate such a correlation was based on all the control unselected lines from both experiments (six in the GE and two in the SI), calculating the correlation between mean and phenotypic variance with the data from all generations. The results of these calculations are shown in the first column of table 4 by
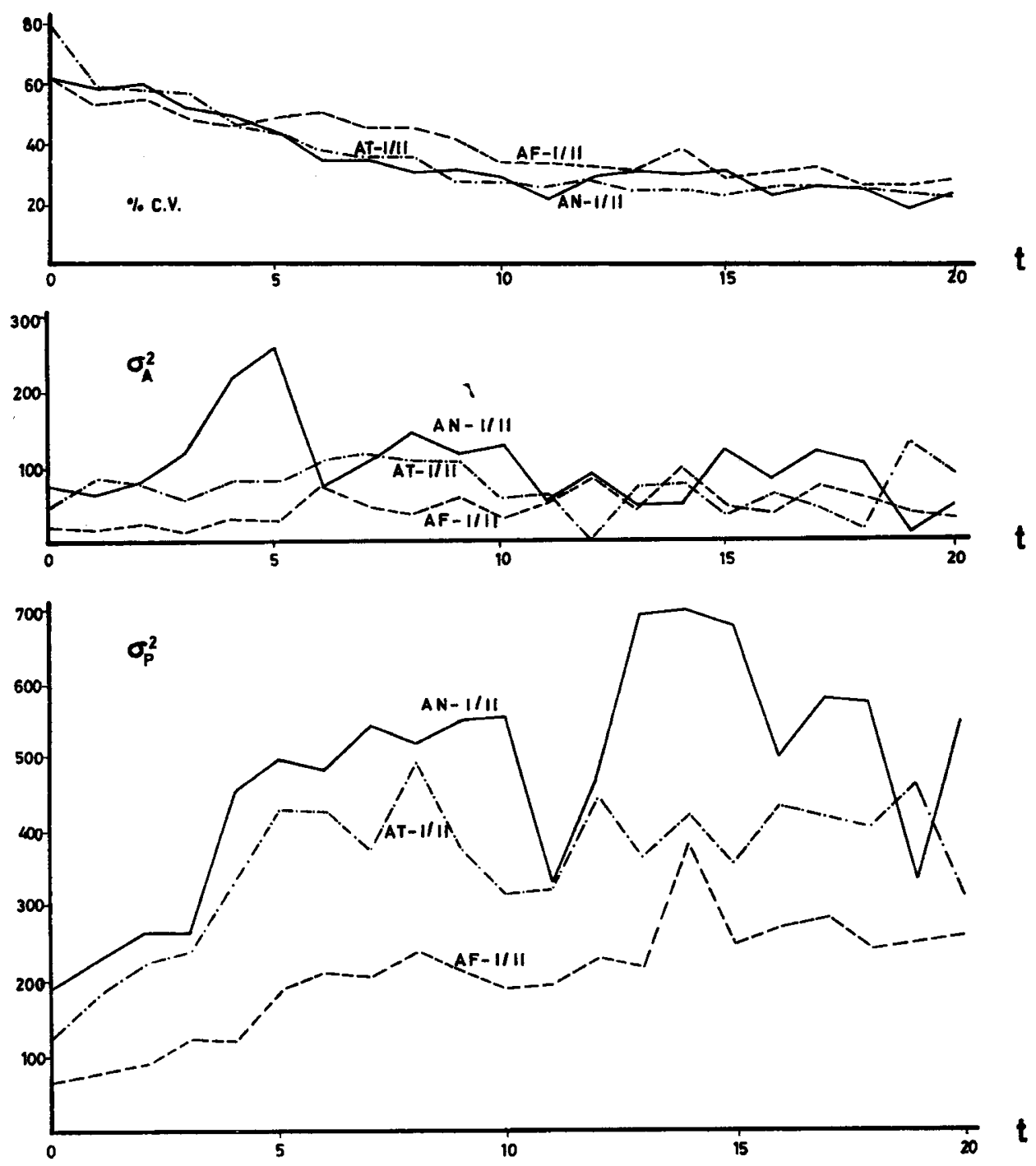

FIG. 3. - Evolution of the phenotypic $\left(\sigma_{\mathrm{P}}^{2}\right)$ and additive genetic $\left(\sigma_{\mathrm{A}}^{2}\right)$ variances and the coefficient of variation (CV) in the $G E$ experiment

Évolution des variances phénotypique $\left(\sigma_{\mathrm{P}}^{2}\right)$ et génétique additive $\left(\sigma_{\mathrm{A}}^{2}\right)$ et coefficient de variation (CV) dans l'expérience GE 

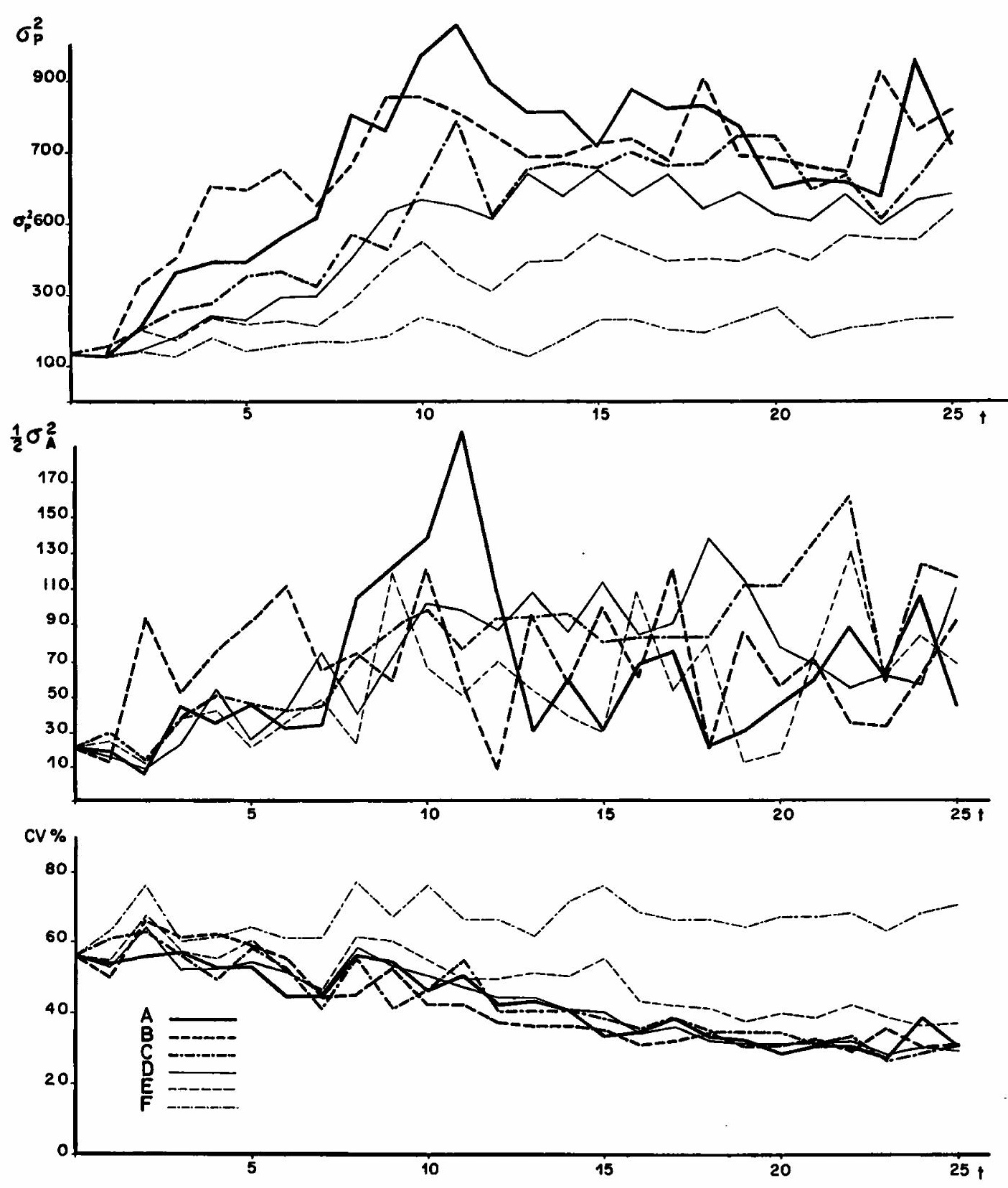

FIG. 4. - Evolution of the phenotypic $\left(\sigma_{\mathrm{P}}^{2}\right)$ and additive genetic variances and the coefficient of variation (CV) in the SI experiment

Évolution des variances phenotypique $\left(\sigma_{\mathrm{p}}^{?}\right)$ et génétique additive et coefficient de variation (CV) dans l'expérience $S I$ 


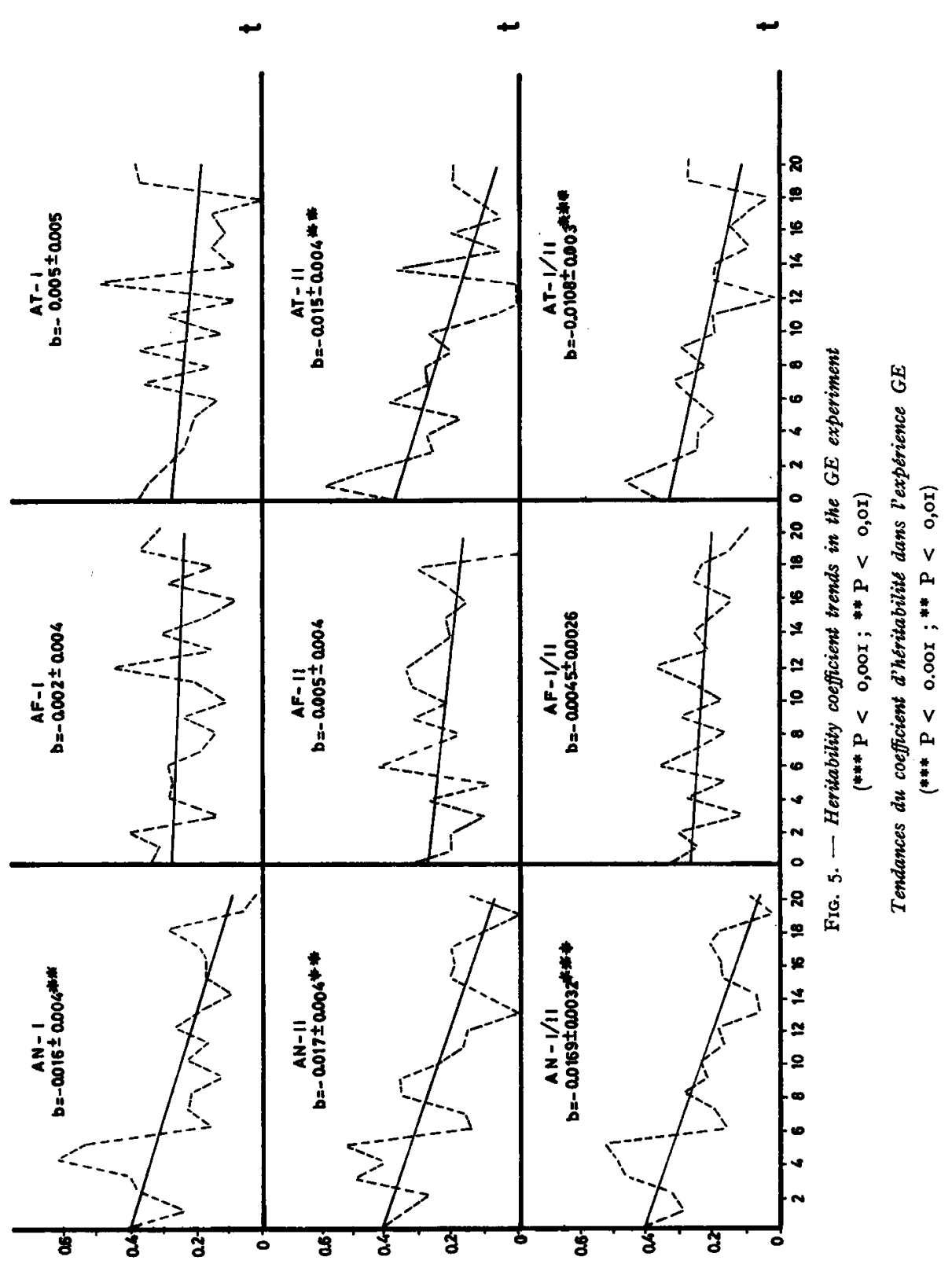




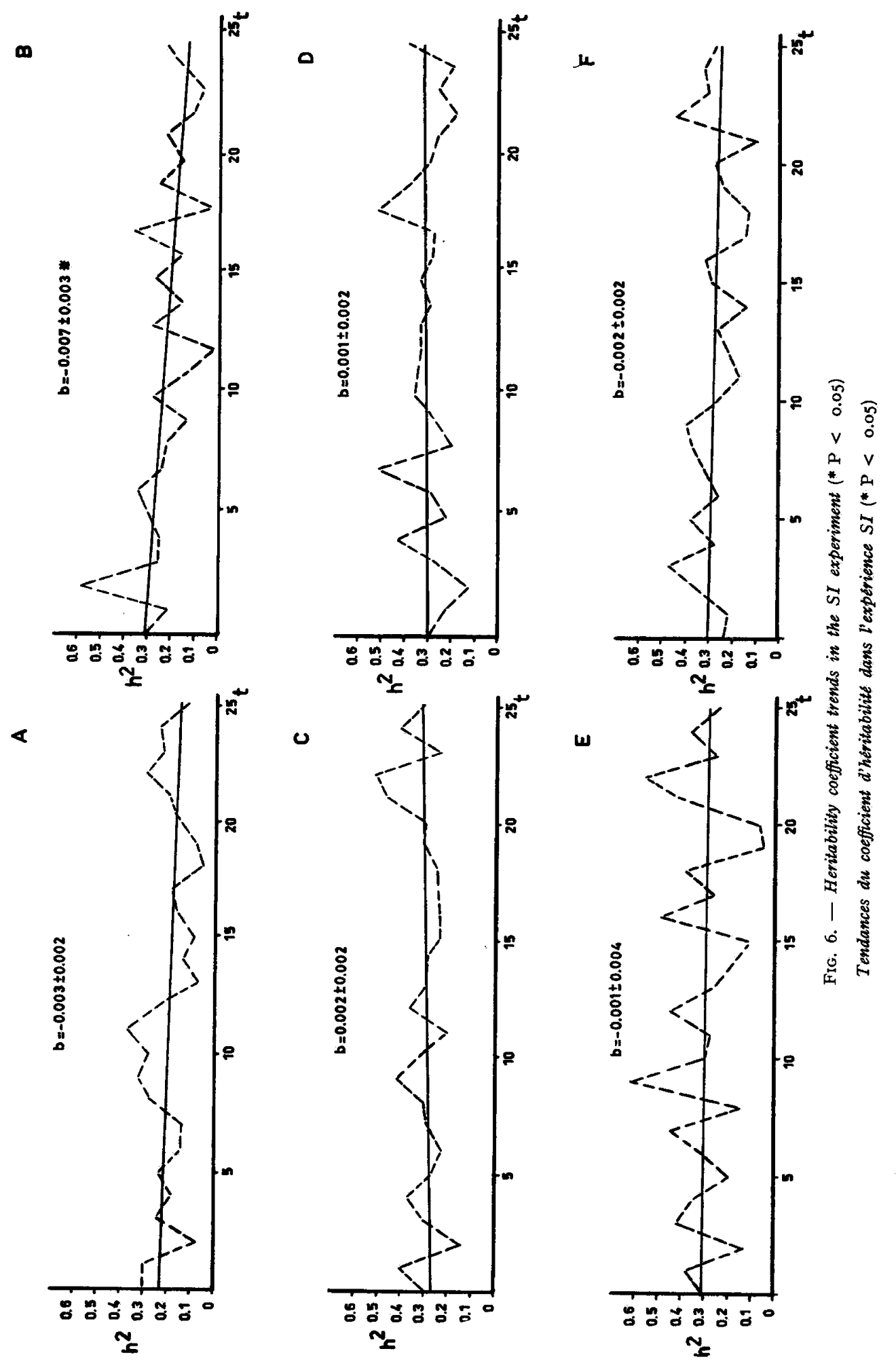


individual lines and by pooling replicates and line types. All those correlations were positive and generally significantly different from zero. Another study was carried out on data for egg laying measured at different time intervals ranging from 2 to I2 days (OROzCo et al., I972), in order to have a larger range of mean values than in the controls where only four-days egg counting was evaluated. Here the correlation was also very high and positive $(0.96 \pm 0.06)$, but the most interesting point is that the linear regression of the phenotypic standard deviation on mean value was $0.35 \pm$ 0.02 which is very alike to the same parameter obtained for the pool of the control lines in the GE experiment : $0.33 \pm 0.05$. Therefore, an adequated transformation of the data is necessary in order to render the mean and the variance uncorrelated in random breeding populations.

We have worked on this topic in quite an extent in relation with the problems of interpreting the behaviour of control lines and its subsequent use for correcting contemporaneous selected lines. A variation in a control unselected line probably does not produce the same additive effect in a selected population. For that reason taking deviations from the control is not enough to correct for the mean in a selected line and probably neither a proportional correction is a good one. An adequate scale has to be found to interprete selection results if they have to be corrected with control fluctuations. Some experiments have been planned to find that adequate scale for measuring egg laying in Tribolium and in chickens, but an ideal transformation has not been found yet. However, we are presenting now a transformation which seems to work, at least in the range found in the upwards selected lines.

First assays were made with the well known logarithmic and square root transformations, but in our case they did not help to uncorrelate means and variances, producing even higher negative correlations.

Considering that the $\mathrm{CV}$ is sometimes an adequated measure of the true variability this parameter was also tested, but the correlation between $\bar{x}$ and CV in the controls gave a high negative value ranging from -0.60 to -0.80 . Furthermore, to use the $\mathrm{CV}$ as a measure of the variability is really to transform the variable $x$ to a new one $z=x / \bar{x}$ and if this transformation changes the correlation from high positive values in the untransformed variable to higher negative ones in the transformed, it was thought that perhaps an intermediate value for the denominator like $\sqrt[4]{\overline{\bar{x}}}$ or $\sqrt{\overline{\bar{x}}}$ could be the best approach for a better transformation, $i$. e., to divide the original variance by $\sqrt{\bar{x}}$ or $x$, respectively.

The correlations between mean and variance for those two transformations are included in the second and third columns of table 4 for each control line and for different pooled values. From those data it is deduced that if the $z=x / \sqrt[4]{\bar{x}}$ transformation could be enough in some cases, in the majority of them the best reduction, or even annulation, of the correlation is obtained with the $z=x / \sqrt{\bar{x}} ; i$.e. dividing the variance by $\bar{x}$.

Using the last transformation the three variances : phenotypic, genetic (additive) and the residual which contains mainly the environmental one, have been revaluated. The results are presented in two ways : graph plotting the average values for each five consecutive generations together with similar values of the untransformed data, which are in figures 7 and 8 for the GE and SI experiments, respectively. Secondly, linear regression coefficients of those transformed data on generations and on means were also calculated and they are in tables 5 to 8 , recognizing that in some cases a 

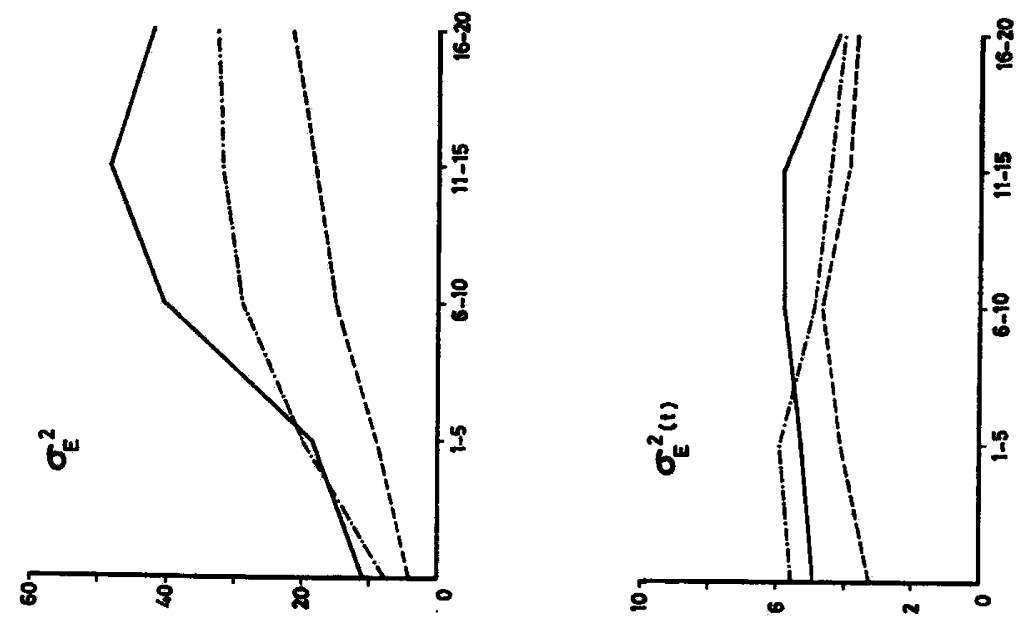


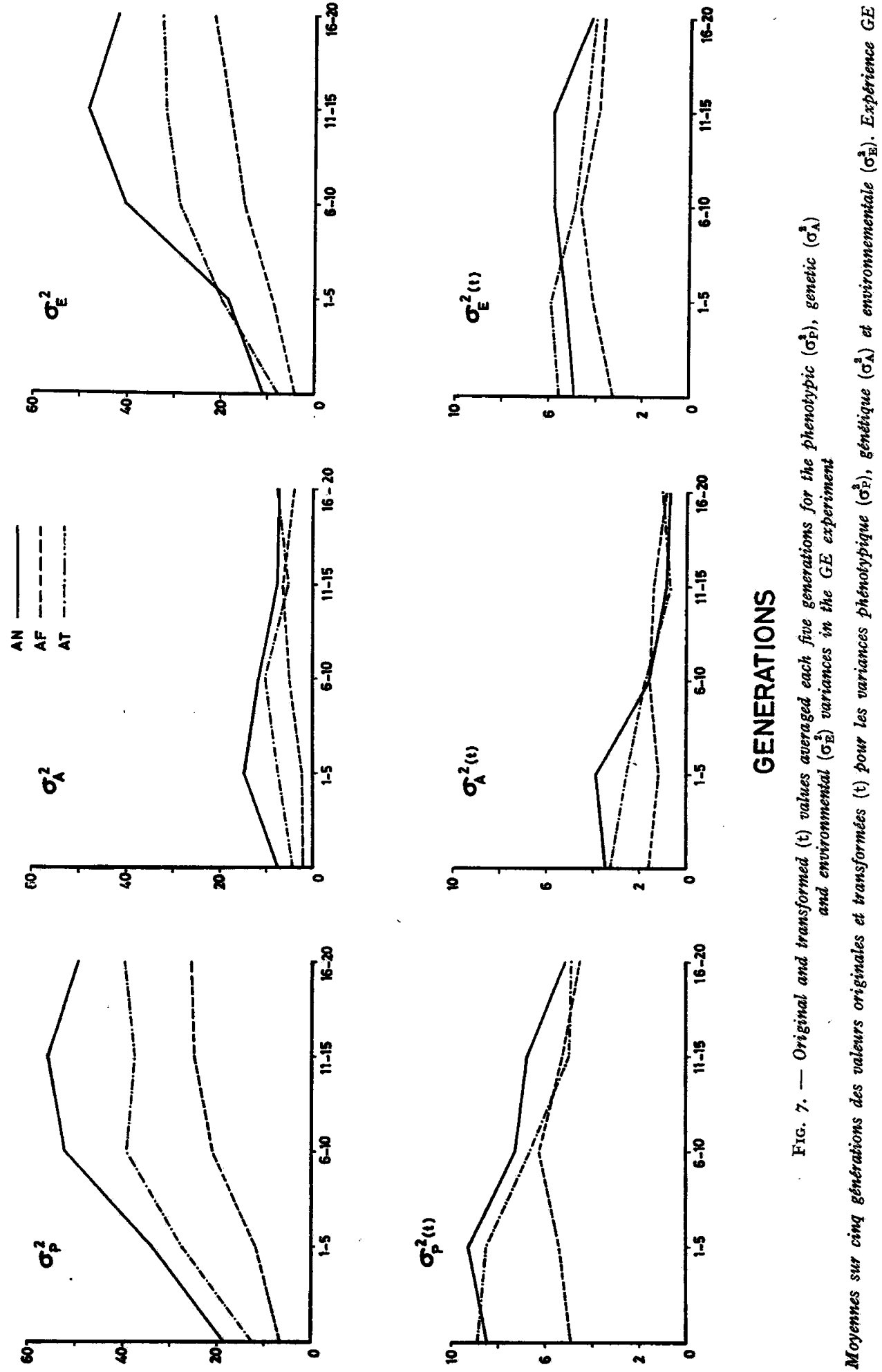

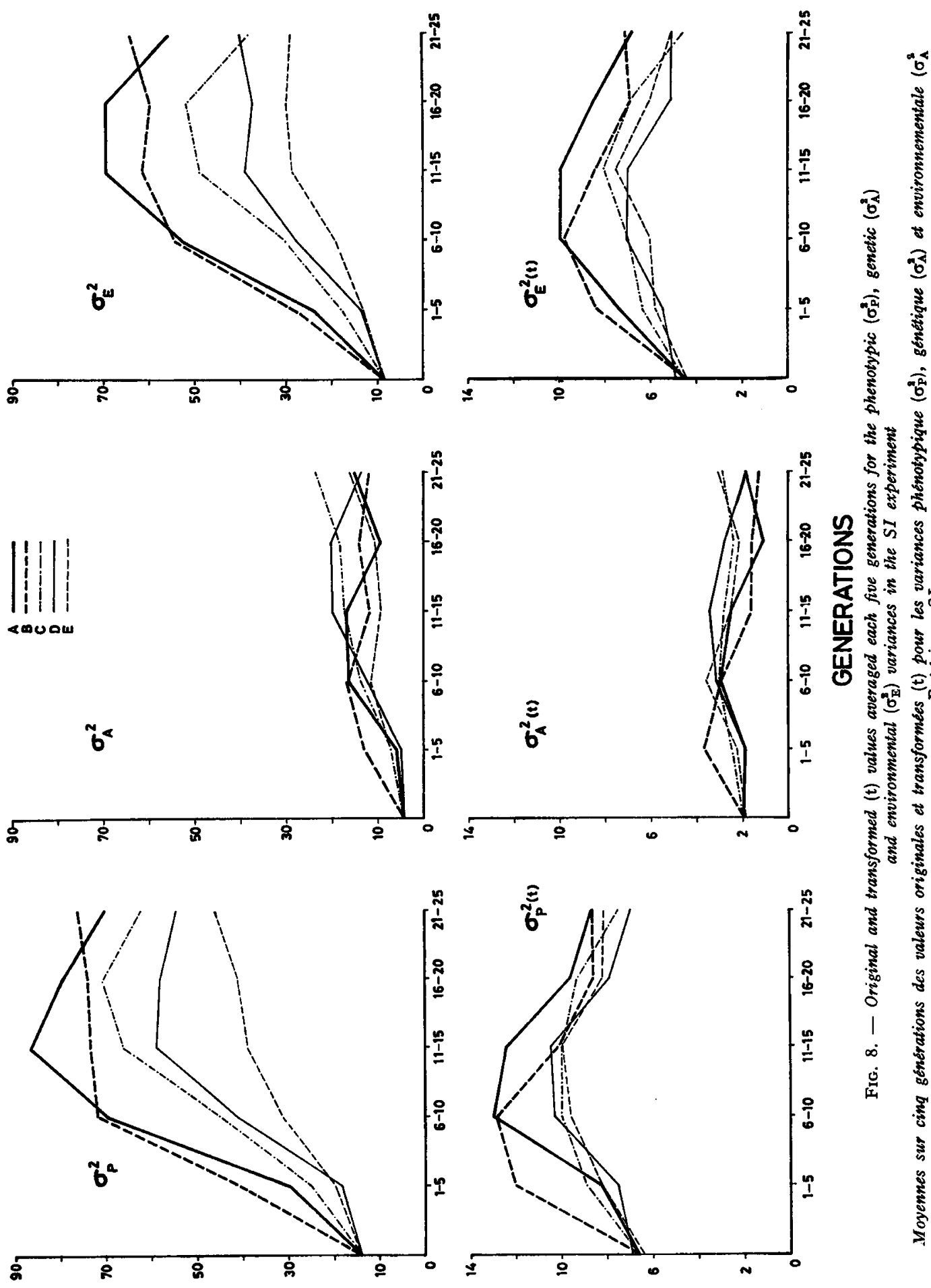

से है है

ก के के

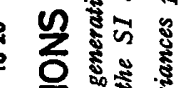

E

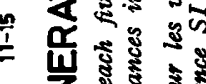

崩

हैं

1 के

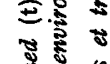

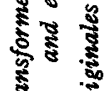


TABLE 4

Correlations between mean and variance for actual data (I) and two types of transformed data:

$\mathrm{x} / \sqrt[4]{\overline{\mathrm{x}}}$ (2) and $\mathrm{x} / \sqrt{\overline{\mathrm{x}}}$ (3)

Corrélations entre les moyennes et variances pour les données actuelles ( $\mathrm{I}$ ) et pour deux types de données transformées:

$\mathbf{x} / \sqrt[4]{\overline{\mathbf{x}}}(2)$ et $\mathbf{x} / \sqrt{\overline{\mathbf{x}}}(3)$

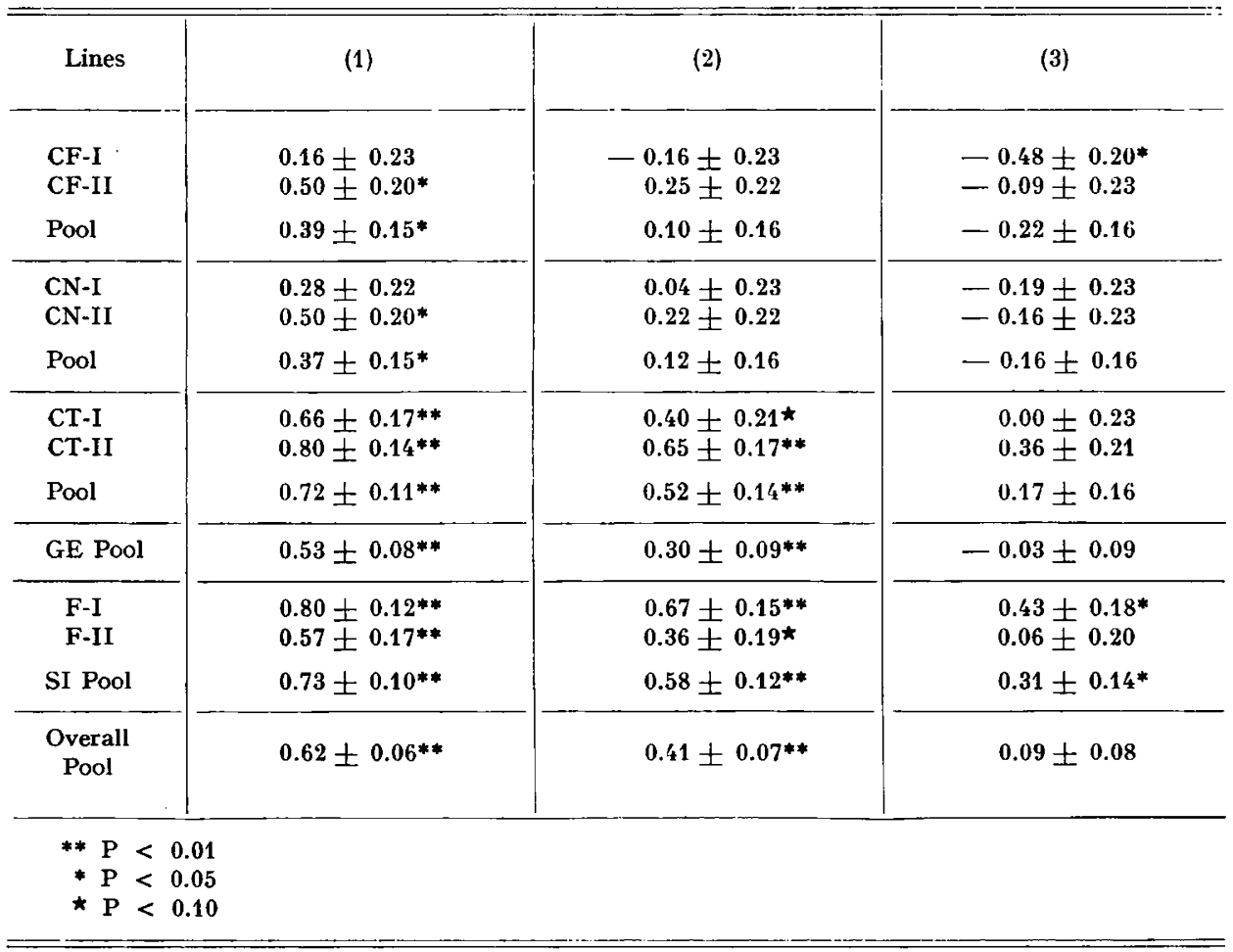

TABLE 5

Linear regression coefficients of corrected variances on generations.

Experiment GE

Coefficients de régression linéaire des variances corrigées sur les générations.

Expérience GE

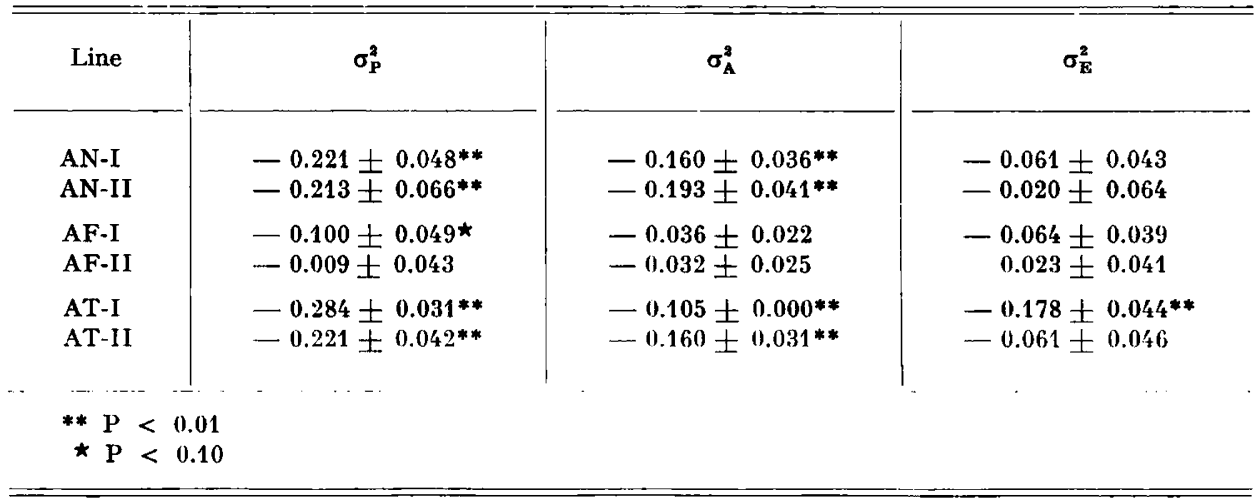


TABLE 6

Linear regression coefficients of corrected variances on mean values.

Experiment GE

Coefficients de régression linéaire des variances corrigées sur les valeurs moyennes. Expérience GE

\begin{tabular}{l|c|c|c}
\hline \hline Line & $\sigma_{\mathbf{P}}^{2}$ & $\sigma_{\mathbf{A}}^{2}$ & $\sigma_{\mathbf{E}}^{2}$ \\
\hline & & & \\
AN-I & $-0.050 \pm 0.011^{* *}$ & $-0.040 \pm 0.007^{* *}$ & $-0.010 \pm 0.010$ \\
AN-II & $-0.052 \pm 0.016^{* *}$ & $-0.047 \pm 0.011^{* *}$ & $-0.005 \pm 0.016$ \\
AF-I & $-0.042 \pm 0.020^{*}$ & $-0.016 \pm 0.009^{*}$ & $-0.026 \pm 0.016$ \\
AF-II & $-0.007 \pm 0.016$ & $-0.012 \pm 0.010$ & $0.005 \pm 0.016$ \\
AT-I & $-0.076 \pm 0.010^{* *}$ & $-0.030 \pm 0.005^{* *}$ & $-0.047 \pm 0.012^{* *}$ \\
AT-II & $-0.058 \pm 0.012^{* *}$ & $-0.045 \pm 0.008^{* *}$ & $-0.013 \pm 0.013$ \\
\hline
\end{tabular}

** $\mathrm{P}<0.01$

$* \mathrm{P}<0.05$

$\star \mathrm{P}<0.10$

TABLE 7

Linear regression coefficients of corrected variances on generations.

Experiment SI

Coefficients de régression linéaire des variances corrigées sur les générations.

Expérience SI

\begin{tabular}{l|c|c|c}
\hline Line & $\sigma_{\mathrm{P}}^{2}$ & $\sigma_{\mathrm{A}}^{2}$ & $\sigma_{\mathrm{E}}^{2}$ \\
& & & \\
\hline A-I & $-0.163 \pm 0.095$ & $-0.055 \pm 0.035$ & $-\cdots 0.08 \pm 0.080$ \\
A-II & $0.084 \pm 0.078$ & $-0.020 \pm 0.053$ & $-0.108 \pm 0.061$ \\
B-I & $-0.189 \pm 0.079^{*}$ & $-0.051 \pm 0.035$ & $-0.138 \pm 0.070^{\star}$ \\
B-II & $-0.096 \pm 0.073$ & $-0.154 \pm 0.045^{* *}$ & $0.058 \pm 0.074$ \\
C-I & $-0.010 \pm 0.056$ & $0.019 \pm 0.028$ & $-0.030 \pm 0.064$ \\
C-II & $-0.065 \pm 0.062$ & $0.002 \pm 0.040$ & $-0.066 \pm 0.057$ \\
D-I & $-0.079 \pm 0.050$ & $-0.003 \pm 0.035$ & $-0.076 \pm 0.046$ \\
D-II & $0.010 \pm 0.057$ & $-0.004 \pm 0.040$ & $0.014 \pm 0.055$ \\
E-I & $0.018 \pm 0.044$ & $-0.038 \pm 0.056$ & $0.056 \pm 0.063$ \\
E-II & $0.002 \pm 0.044$ & $0.033 \pm 0.045$ & $-0.031 \pm 0.056$ \\
\hline
\end{tabular}

\footnotetext{
** $P<0.01$

* $\mathbf{P}<0.05$

$\star \mathrm{P}<0.10$
} 


\section{TABLE 8}

Linear regression coefficients of corrected variances on mean values. Experiment SI

Coefficients de régression linéaire des variances corrigées sur les valeurs moyennes. Expérience SI

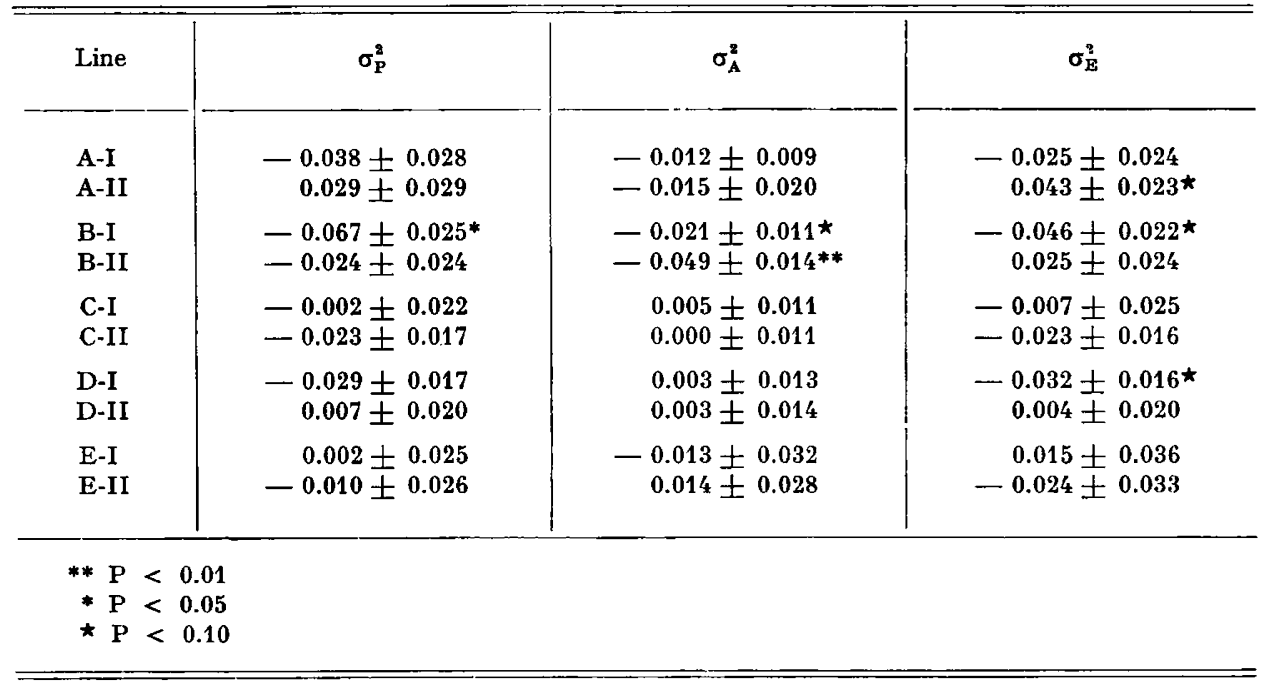

TABLE 9

Variances of transformed data for pure lines and crosses (boldfaced type) in a reciprocal recurrent selection scheme.

Average of five generations periods. Replications pooled

Variances des données transformées pour les lignées pures et pour les croisements (chiffres gras) dans un schéma de sélection récurrente réciproque.

Moyenne sur cinq générations. Répétitions groupées

\begin{tabular}{|c|c|c|c|c|c|c|c|c|c|}
\hline \multirow{3}{*}{$\begin{array}{l}\text { Types of } \\
\text { Lines and } \\
\text { Crosses }\end{array}$} & \multicolumn{3}{|c|}{$\sigma_{\mathrm{P}}^{2}$} & \multicolumn{3}{|c|}{$\sigma_{A}^{\prime}$} & \multicolumn{3}{|c|}{$\sigma_{\mathrm{E}}^{2}$} \\
\hline & \multicolumn{3}{|c|}{ Generations } & \multicolumn{3}{|c|}{ Generations } & \multicolumn{3}{|c|}{ Generations } \\
\hline & 0 & $1-5$ & $6-10$ & 0 & $1-5$ & $6-10$ & 0 & $1-5$ & $6-10$ \\
\hline F & 4.97 & $\begin{array}{l}5.60 \\
5.51\end{array}$ & $\begin{array}{l}6.63 \\
5.86\end{array}$ & 1.66 & $\begin{array}{l}1.66 \\
1.57\end{array}$ & $\begin{array}{l}1.45 \\
1.98\end{array}$ & 3.31 & $\begin{array}{l}3.93 \\
3.94\end{array}$ & $\begin{array}{l}5.18 \\
3.89\end{array}$ \\
\hline $\mathbf{N}$ & 8.45 & $\begin{array}{l}8.90 \\
8.38\end{array}$ & $\begin{array}{l}9.94 \\
8.94\end{array}$ & 3.46 & $\begin{array}{l}2.95 \\
2.48\end{array}$ & $\begin{array}{l}2.69 \\
3.04\end{array}$ & 4.99 & $\begin{array}{l}5.95 \\
5.89\end{array}$ & $\begin{array}{l}7.25 \\
5.90\end{array}$ \\
\hline $\mathrm{T}$ & 8.88 & $\begin{array}{l}8.31 \\
9.78\end{array}$ & $\begin{array}{l}9.73 \\
8.88\end{array}$ & 3.28 & $\begin{array}{l}2.42 \\
3.91\end{array}$ & $\begin{array}{l}1.48 \\
2.97\end{array}$ & 5.60 & $\begin{array}{l}5.90 \\
5.86\end{array}$ & $\begin{array}{l}8.25 \\
5.91\end{array}$ \\
\hline
\end{tabular}


linear trend is not enough to interpret the actual tendency as shown in the graphs.

From the results in tables 5 to 8 it appears that the observed trends for the transformed variances are essentially the same when regressed either on the means or on generation number.

Finally, table 9 presents the transformed data of the same three types of variances from a reciprocal recurrent selection scheme also from the GE experiment. Those data are the averages for the two first periods of five generations, including values of pure lines and crosses, together with the generation zero data.

\section{DISCUSSION}

The trend for the transformed phenotypic variances indicates a very well defined reduction, mainly in the AN and AT lines which were the ones with better response to selection in the GE experiment. The $\mathrm{F}$ lines of that experiment also present such a decrease but it is only significant in one replicate. In SI experiment there is also, in general, a negative trend for the phenotypic variances. Most of these reductions of the phenotypic variances are due to a parallel decrease of the genetic variance. The evolution of the environmental variance is rather erratic with a tendency to stand nearly constant. So, in general, the decrease of the phenotypic variance is due to the decrease of the genetic one.

When observing the graphs in figure 7 and 8 it is interesting to note the different pattern presented by the transformed variances compared with the original ones. Nothing new is found in connection with the GE experiment which were not explained by the regression coefficients, because no important curvilinear trend is observed. However in the SI experiment both in the phenotypic as well as in the $\sigma_{\mathrm{E}}^{2}$ a trend seems consistent : a slight increase followed by a posterior decrease, whilst in the $\sigma_{A}^{2}$ the slight but persistent decrease seems to be the rule. The only difference between the two experiments was that family selection in both males and females was applied in the GE whilst only individual selection on females was made in the SI. In this way, the mating of selected females with males taken at random surely produces a larger variability in the character during the early generations ; variability that is expected to be reduced later when the selection progresses and the males came from less variable populations.

The negative trend observed in the $\sigma_{A}^{2}$ is also in agreement with the trend found in the heritabilities. Similar comparison can be made in the lines of the SI experiment, where the only heritability with a significant decrease was found for the B lines with no apparent decrease in the other ones. This non decreasing trend was schown to be due to lack of precision of the estimates (RUANo et al., I975).

If a lack of response to selection when some additive variance still remains is due to the selection of heterozygous " loci ", two situations are generally being considered (CLAYTON and RoBERTSON, I957) : overdominance genes for the direct expression of the trait, or overdominance for fitness whatever the type of gene action for the measured trait. Even recognizing that it is difficult to attribute in each case only one type of action, we have reasons to think that in the egg lay of Tribolium the second case is relatively much more important. Firstly, it was shown a very important 
deterioration of fitness components as the selection was progressing in each type of selection with our lines (Orozco, I972). Secondly, the relative importance of dominance in the expression of the trait in a stress environment and the subsequent better response of a reciprocal recurrent selection in the stronger stress conditions, but not in the optimal ones, indicates that probably the non-additive genes responsible in those situations for the expression of trait could not be directly responsible of it but rather of a resistance to adverse conditions which is necessary for the expression of the trait.

The environmental variance does not show much variation where the transformed data are observed, at least in the GE experiment. But in order to go a step more in checking the goodness of the transformation; data from a reciprocal recurrent selection scheme included in that GE experiment have been analysed. The most important observation from these data is that if for the pure lines the $\sigma_{E}^{2}$ during the second period largely increases, it remains nearly constant for the crosses, as expected when considering the buffering qualities of the crosses with regards to the environment. Concerning the $\sigma_{A}^{2}$, there is a reduction with selection in the pure lines meanwhile in the crosses that reduction is not shown as clearly ; more probably due to a better precision in the estimation because of that buffering qualities referred above than to a real constancy of the additive fraction of the total variation (OROzCO, 1974). The effect of larger $\sigma_{E}^{2}$ in pures than in crosses is so important that even the $\sigma_{P}^{2}$ is still larger in the pure lines, in spite of the decrease of the $\sigma_{A}^{2}$.

In our opinion the anarchical situation observed during the last period of generations of selection above referred to, mainly concerning with anomalous high estimations of additive variance, could be also attributed to biased values obtained because of the use of a non-adequate scale. One is not sure if the present tentative change of variable should be correct also for that late stage of selection, but other ones in the line of using fractional potencies of the mean for the denominator are being now assayed by calculating regressions of logarithms of variances on logarithms of means with egg laying data of a large range of egg production. There is also a hope that this study may draw light on the problem of correcting selected lines with control unselected populations.

Reçu pour publication en juin 1975.

\section{RÉSUMÉ}

\section{CHANGEMENT D'ÉCHELLE DANS L'ÉTUDE DE L'ÉVOLUTION DE LA VARIANCE GÉNÉTIQUE AVEC LA SÉLECTION CHEZ TRIBOLIUM CASTANEUM}

On a étudié, dans deux expériences séparées, où l'on a sélectionné pour une ponte plus élevée des femelles vierges de Tribolium castaneum, l'évolution des variances phénotypique, génétique et environnementale au fur et à mesure que la sélection avance.

Dans les lignées témoins (non sélectionnées) on a trouvé une corrélation très élevée entre la moyenne et la variance phénotypique. Nous avons alors cherché une transformation appropriée pour éliminer cet effet d'échelle. On a trouvé que la meilleure transformation, c'est-à-dire, celle dans laquelle il n'y a pas de corrélation entre la moyenne et la variance était $: Z=x / \sqrt{\bar{x}}$, où $Z$ est la nouvelle variable.

En utilisant la transformation indiquée dans les populations sélectionnées, l'augmentation spectaculaire de la variance phénotypique observée dans les lignées a diminué et l'on a pu mieux 
se rendre compte de l'évolution, au fur et à mesure que la sélection avançait. On a fait l'étude de cette évolution en considérant sa relation avec les différents niveaux atteints par la sélection du caractère considéré et le type de sélection appliqué.

L'absence d'une diminution de la variance génétique observée dans les lignées sélectionnées est discutée du point de vue d'une supériorité des hétérozygotes, soit qu'il existe une overdominance pour le caractère sélectionné ou une overdominance pour les caractères directement responsables de la reproduction. Ces résultats sont également discutés en relation avec la détérioration de l'efficacité biologique dans les lignées sélectionnées et l'importance progressive de la variance non-additive quand le caractère est mesuré dans des environnements moins favorables.

On insiste sur l'importance d'une transformation des données pour interpréter correctement les résultats des expériments de la sélection, spécialement pour estimer les paramètres et pour effectuer les corrections adéquates selon les populations témoins.

\section{REFERENCES}

Bulmer M. G., r971. The effect of selection on genetic variability. The American Naturalist, 105, 2OI-2II.

Clayton G. A., Robertson A., 1957. An experimental check on quantitative genetical theory. II. The long-term effects of selection. Journal of Genetics, 55, 152-170.

Crow J. F., Kimura M., 1970. An Introduction to Population Genetics Theory. Harper and Row, New York, p. 236-239.

Orozco F., I974. A dynamic study of genotype-environment interaction with egg laying of Tribolium castaneum. Heredity (submitted).

Orozco F., Bell A. E., I974a. A genetic study of egg-laying of Tribolium in optimal and stress environments. Canadian Journal of Genetics and Cytology, 16, 49-60.

Orozco F., Bell A. E., I974 b. Reciprocal recurrent selection compared in optimal and stress environments to within-strain selection for increasing the rate of egg lay of Tribolium. Gemetics, 77, $143-161$.

Orozco F., CAmpo J. L., TAgarro P., I972. Influencia de diversos factores en la puesta del Tribolium castaneum. Anales del Instituto Nacional de Investigaciones A grarias (General), 2, 37-52.

Ruano R. G., Orozco F., Lopez-Fanjul C., I975. The effect of different selection intensities on selection response in egg-laying of Tribolium castaneum. Genetical Research, 25, 17-27. 